Research article

VERSITA

DOI: $10.2478 / \mathrm{rrlm}-2013-0024$

\title{
Eosinophil activation markers in clonal and non-clonal eosinophilia
}

\section{Markeri de activare a eozinofilelor în eozinofilii clonale şi non-clonale}

\author{
Silvana Angelescu ${ }^{1,2^{*}}$, Cristina Mambet ${ }^{3}$, Delia I Mut Popescu ${ }^{1,2}$, \\ Nicoleta M Berbec ${ }^{1,2}$, Andra Costache ${ }^{1,2}$, Mihai Isaroiu ${ }^{4}$, Anca R Lupu ${ }^{1,2}$ \\ 1. Carol Davila University of Medicine and Pharmacy, Bucharest, Romania \\ 2. Coltea Clinical Hospital, Bucharest, Romania \\ 3. Central Laboratory Synevo, Chiajna- Ilfov, Romania \\ 4. Polytechnic University of Bucharest, Romania
}

\begin{abstract}
Eosinophils are leukocytes with multiple functions in physiologic and pathologic circumstances. Eosinophilia is typically associated with reactive conditions (helmintic infections, allergic or drug reactions and atopic disorders) and sometimes with hematologic and non-hematologic malignancies. Evaluation of a patient with eosinophilia requires numerous imaging investigations and laboratory tests for establishing the right treatment. We measured the degree of eosinophilic activation using serologic biomarkers such as serum eosinophil cationic protein (ECP), interleukin-5 (IL-5) and eosinophilic cationic protein/eosinophil count (ECP/Eo) ratio in order to differentiate earlier among distinct eosinophilic conditions: clonal, non-clonal with malignancy and reactive eosinophilia with inflammation. The median ECP value in eosinophilic patients was significantly higher when compared to that of the control group (19.55 vs. $4.93 \mathrm{ng} / \mathrm{mL}, \mathrm{p}<0.05)$. Within patients with eosinophilia, the clonal eosinophilia group showed a significantly higher median ECP value compared to the median ECP values of the non-clonal eosinophilia groups - (30.15 vs. $19.5 \mathrm{ng} / \mathrm{mL}, p<0.05$ and respectively $30.15 \mathrm{vs} .13 .3 \mathrm{ng} / \mathrm{mL}$, $p<0.05)$. Also patients having non-clonal eosinophilia with malignancy had a significantly higher median ECP value compared to those of reactive eosinophilia and inflammation (19.5 vs. $13.3 \mathrm{ng} / \mathrm{mL}, \mathrm{p}<0.05)$. While ECP serum levels seemed to be a discriminatory tool for different groups of eosinophilic patients IL-5 and ECP/EO were less useful for this purpose. However our results must be confirmed in larger studies.
\end{abstract}

Keywords: Eosinophilia, eosinophil cationic protein, interleukin 5, absolute eosinophil count.

\section{Rezumat}

Eozinofilele sunt leucocite multifuncționale, implicate în numeroase procese fiziologice şi patologice. Eozinofilia este asociată de obicei cu infecții parazitare, alergii, reacții la medicamente, tulburări atopice şi uneori cu neoplazii hematologice sau tumori solide. Evaluarea unui pacient cu eozinofilie necesită efectuarea a numeroase teste imagistice şi de laborator pentru elucidarea mecanismului eozinofiliei şi stabilirea tratamentului

${ }^{*}$ Corresponding author: Silvana Angelescu - Coltea Clinical Hospital 1-3, I.C. Bratianu, Bucharest, Romania Tel.: +40213874100/172, Fax: 0213874101, Email: eangelescu@clicknet.ro 
corect. Scopul studiului de față a fost măsurarea activității eozinofilelor utilizând ca markeri serologici nivelele serice ale proteinei cationice eozinofilice (ECP), interleukinei 5 (IL-5) şi raportul dintre ECP şi numărul absolut al eozinofilelor în sângele periferic $(E C P / E o)$ în vederea diferențierii precoce a eozinofiliei clonale de cea nonclonală (asociată cu malignități sau cu inflamație). Grupul pacienților cu eozinofilie a înregistrat o valoare mediană ECP semnificativ mai mare in comparație cu cea a lotului martor (19.5 vs. 4.93 ng/mL, p<0.05). La pacienții cu eozinofilie clonală am observat o valoare mediană ECP mult mai mare, statistic semnificativă, comparativ cu valorile mediane ECP asociate grupurilor de eozinofilie non-clonală (30.15 vs. $19.5 \mathrm{ng} / \mathrm{mL}, p<0.05$ şi respectiv 30.15 vs. $13.3 \mathrm{ng} / \mathrm{mL}, p<0.05)$. De asemenea, pacienții cu eozinofilie non-clonală şi malignități au prezentat o valoare mediană ECP semnificativ mai mare in comparație cu grupul având eozinofilie reactivă asociată cu inflamație (19.5 vs. $13.3 \mathrm{ng} / \mathrm{mL}, \mathrm{p}<0.05)$. In timp ce valorile ECP in ser s-au dovedit a fi un instrument ce permite diferențierea grupurilor de pacienți cu eozinofilie IL-5 si ECP/Eo au fost mai puțin utile in acest scop. $C$ u toate acestea rezultatele noastre trebuie confirmate pe loturi mai mari de pacienți.

Cuvinte cheie- Eozinofile, proteina cationică eozinofilă, interleukina-5, număr absolut eozinofile

Received: $31^{\text {st }}$ January 2013; Accepted: $9^{\text {th }}$ June 2013; Published: $9^{\text {th }}$ September 2013.

\section{Introduction}

The eosinophil was discovered by Paul Ehrlich in 1879 (1) and even though research work focused on eosinophil morphology, physiology and circulation to peripheral blood and tissues, the functions of these cells in physiological or pathological circumstances have been disputed (2). The traditional roles of eosinophils were associated with allergic diseases or responses to parasitic infections (2). This view has become more nuanced and now eosinophils are considered multifunctional leukocytes, true immunoregulatory cells with roles which imply: increase fibrosis, vascular leakage, angiogenesis, epithelial desquamation, epithelial metaplasia and smooth muscle hypertrophy (3). Recent studies suggest that instead of destructive endstage effector cells, eosinophils play an important role in regulating local immunity and in remodeling/repairing processes, either in normal conditions (plasma cells survival, thymic development and T-cell selection, metabolic homeostasis, female reproductive system, mammary gland development, reproductive homeostasis) and also in pathological conditions (cancer and tumor biology, transplant rejection, demyelinating diseases, pulmonary hypertension, acute lung injury, eosinophilic esophagitis, inflammatory bowel disease, allergic/chemical contact dermati- tis) (3). Eosinophils represent approximately 1$5 \%(<500$ cells $/ \mu 1)$ of all blood leukocytes. Eosinophilia is defined as an abnormal increase of eosinophils in different tissues or in peripheral blood. The degree of eosinophilia can be classified into mild (500 to 1500 cells $/ \mu \mathrm{l}$ ), moderate (1500 to 5000 cells $/ \mu \mathrm{l}))$ or severe $(>5000$ cells $/ \mu 1$ ) (4). An attempt to differentiate the causes of eosinophilia, indicates eosinophilic diseases as clonal or non-clonal (5).

1. Clonal disorders associated with eosinophilia. Clonal eosinophilia represents a neoplastic proliferation of eosinophils as a component of an intrinsic stem cell or myeloid malignancy (5). This category comprises mostly chronic myeloproliferative syndromes: chronic myeloid leukemia (CML), polycythemia vera, essential thrombocythemia, eosinophilic leukemia, 8p11 syndrome, systemic mastocytosis (SM), myelodysplastic syndromes (MDS) with eosinophilia, acute myeloid leukemia (AML), especially with chromosome 16 anomalies and some lymphoid disorders - precursor B-cell acute lymphoblastic leukemia with $\mathrm{t}(5 ; 14)$ and precursor T-cell lymphoblastic lymphoma with $\mathrm{t}(8 ; 13)$. In such cases we may detect the presence of the fusion genes which involve platelet-derived growth factor receptor alpha (PDGFRA), platelet derived growth factor receptor-beta (PDGFRB), fibroblast growth fac- 
tor receptor 1 (FGFR1) or other tyrosine kinases (6). The importance of these findings lies in the efficiency of imatinib treatment in patients with PDGFRA or PDGFRB fusion genes, but not in FGFR1 fusion genes positive cases.

2. Non-clonal (reactive) eosinophilia (5) - is explained by stimulation of cytokine production by $\mathrm{T}$ cells. Non-clonal eosinophilia can be divided in 2 categories:

- Reactive eosinophilia with malignancy: Hodgkin and non-Hodgkin lymphomas, other lymphoproliferative disorders and solid tumors which are included here because eosinophils have not been demonstrated as being a component of the malignant clone (7).

- Reactive eosinophilia with inflammation is frequent in allergic-, autoimmune-, infectious-, graft-versus-host -diseases, immunologic deficiencies, idiopathic eosinophilia, reactions to drugs, skin and connective tissue disorders (7).

3. Idiopathic hypereosinophilic syndrome (IHES) - Patients with persistent $(>6$ months), unexplained eosinophilia (>1500/ $\mu \mathrm{L})$ and organ-damage are diagnosed with IHES (8).

Eosinophilia accompanies various diseases, some of them relatively common in clinical practice. The conventional investigation of patients with eosinophilia comprise: careful anamnesis, routine laboratory tests, bone marrow aspirate, genetic and molecular markers and evaluation of potentially affected organs. A non-invasive, specific laboratory test, with a high degree of sensitivity and specificity would be necessary to facilitate an earlier distinction between clonal and reactive eosinophilia. Previous reports have shown that plasma IL-5 and ECP levels may reflect the degree of eosinophilic activation and could differentiate between clonal and non-clonal eosinophilia (9). IL-5 is produced by lymphocytes, eosinophils and malignant cells and is essential for maturation, chemotaxis, activation, trafficking and for recruitment of eosinophils in areas of tissue inflammation (9). ECP is a cytotoxic protein contained within eosinophil specific granules.
Plasma or serum ECP levels may indicate eosinophilic activity or the degree of activation (10). Some recent studies have shown that ECP/Eo ratio might represent a better biomarker than using serum ECP and eosinophilic blood count independently (9). We used serum ECP, ECP/Eo ratio, IL-5 and bone marrow eosinophil percentage to find out whether the eosinophil activity is different in patients with clonal than in non-clonal eosinophilia, but also between nonclonal hematologic malignancies with eosinophilia and solid tumors. We also tried to determine the diagnostic value of these serological parameters in early differentiation among various eosinophilic diseases.

\section{Materials and methods}

We investigated 69 eosinophilic patients, divided in 3 categories: clonal eosinophilia, nonclonal (reactive) eosinophilia in neoplastic (hematologic and non hematologic) diseases and reactive eosinophilia in inflammatory conditions. We compared data from eosinophilic patients group with 20 non-eosinophilic subjects (control group). We also analyzed the eosinophilic activation degree within the above mentioned 3 categories of eosinophilic patients.

For each patient and control group subject we determined: serum ECP value expressed in $\mathrm{ng} / \mathrm{mL}$, the amount of IL-5 expressed in $\mathrm{pg} / \mathrm{mL}$, the absolute eosinophil count in peripheral blood (Eo) expressed as number of cells/ $\mu 1$ and ECP/Eo ratio (by calculation). The percentage of BM eosinophils was calculated after examining at least 500 nucleated cells, using the BM differential count. We did not perform bone marrow aspiration in control group subjects. Leukocyte count, differential white blood count and the absolute eosinophil count in peripheral blood were performed using Sysmex analyzer (XT-1800i). Percentages of eosinophils were evaluated also by microscopic examination of peripheral blood smear. Serum ECP determinations were performed by a chemiluminescence 
immunoassay (Immulite 2000, Siemens) and the IL-5 in serum by ELISA (DRG Diagnostics kit, Germany) according to the instructions of the manufacturer. Until processing, serum samples aliquots were kept at $-80^{\circ} \mathrm{C}$ in Eppendorf microtubes. Serum concentration of ECP per eosinophil was calculated as ratio of serum ECP concentration $(\mu \mathrm{g} / \mathrm{L})$ to eosinophilic blood count- Eo (cells/ $\mu \mathrm{l})$ and expressed as ECP/Eo ratio after the formula: $\mathrm{ECP} / \mathrm{Eo}$ ratio $=\mathrm{ECP}$ $(\mu \mathrm{g} / \mathrm{L}) /$ number of eosinophils (cells $/ \mu \mathrm{l})$.

Statistical tests were performed using $\mathrm{R}$ software (a GNU project developed by Lucent Technologies). Due to the fact that all continuous variables were not normally distributed median value and the inter-quartile range (IQR) of the data set were used. Further, differences between ECP, IL-5 and ECP/Eo values corresponding to control group and different groups of patients were assessed by Median test, applicable for non-normally distributed data and small sample sizes (11-13).

The present study was performed with informed consent of the patients for research and data publication, according to the World Medical Association Declaration of Helsinki, revised in 2000, Edinburgh.

\section{Results}

We investigated 69 eosinophilic patients - with clonal eosinophilia $(\mathrm{n}=28)$, nonclonal (reactive) eosinophilia in neoplastic diseases $(n=25)$, reactive eosinophilia in inflammatory conditions $(\mathrm{n}=16)$ - and 20 noneosinophilic subjects (control group). Clonal eosinophilia group consisted of patients with $\operatorname{AML}(n=6), \operatorname{CML}(n=17), \operatorname{MDS}(n=4)$ and SM $(n=1)$. Chronic lymphoproliferative disorders and non-hematologic neoplasms (solid tumors) were categorized as non-clonal eosinophilia with malignancy. In this category, we investigated 20 patients with lymphoproliferative syndromes: T-cell non Hodgkin lymphoma -NHL $(\mathrm{n}=3)$, B-cell NHL $(n=8)$, Hodgkin lymphoma - HL $(\mathrm{n}=1)$, Chronic Lymphocytic Leukemia - CLL $(\mathrm{n}=4)$, Multiple myeloma $-\mathrm{MM}(\mathrm{n}=4)$ and 5 patients with solid tumors: colon $(\mathrm{n}=2)$, lung $(\mathrm{n}=1)$, uterine $(\mathrm{n}=2)$. We considered as reactive eosinophilia with inflammation the following conditions: rheumatoid arthritis $(\mathrm{n}=1)$, toxoplasmosis infection $(n=1)$, idiopathic thrombocytopenic purpura $(\mathrm{n}=6)$, megaloblastic anemia $(n=4)$ and hemolytic anemia $(n=4)$. The eosinophilic patients had blood eosinophilia (>600 cells $/ \mu \mathrm{l}$ ) and /or BM eosinophilia (>8\% mature and immature eosinophils).

In Table 1 we included serum levels of ECP and IL-5, the absolute eosinophil count in peripheral blood (Eo) and ECP / Eo ratio in the control group and in eosinophilic patients (overall and by category of disease). We also noted patients' percentage of eosinophils in bone marrow (BM- Eo). Data are expressed as medians with inter-quartile range (IQR) in parenthesis.

Compared to control group, in eosinophilic patients we report higher ECP values (median, IQR) statistically significant (19.55 $\mathrm{ng} / \mathrm{mL}, 11.5-31.4$ vs. $4.93 \mathrm{ng} / \mathrm{mL}, 3.67-6.32$, $\mathrm{p}<0.05)$. Within patients with eosinophilia, the clonal eosinophilia group showed significantly higher ECP levels (median, IQR) compared to those of the non-clonal eosinophilia groups $(30.15 \mathrm{ng} / \mathrm{mL}, 12.23-143.2$ vs. $19.5 \mathrm{ng} / \mathrm{mL}, 14.8-$ $25.7, \mathrm{p}<0.05$, and respectively $30.15 \mathrm{ng} / \mathrm{mL}$, 12.23-143.2 vs. $13.3 \mathrm{ng} / \mathrm{mL}, 8.16-19.1, \mathrm{p}<0.05)$. On the other hand, patients having non-clonal eosinophilia with malignancy had significantly higher serum ECP levels (median, IQR) compared to those of reactive eosinophilia and inflammation $(19.5 \mathrm{ng} / \mathrm{mL}, 14.8-25.7$ vs. 13.3 ng/mL, 8.16-19.1, p<0.05) Figure1.

Thus, ECP levels were useful in distinguishing between different eosinophilia groups.

Compared to control group, eosinophilic patients had higher IL-5 values (median, IQR) statistically significant $(2.16 \mathrm{pg} / \mathrm{mL}, 1.74-2.72$ vs $1.88 \mathrm{pg} / \mathrm{mL}, 1.52-2.19, \mathrm{p}<0.05)$.

However, in clonal eosinophilia vs. nonclonal eosinophilia groups there were no significant 
Table 1. Levels ECP, IL-5, Eo, ECP / Eo ratio and BM -Eo patients and control group

\begin{tabular}{lcccccc}
\hline Groups & $\begin{array}{c}\text { Patients } \\
\text { No. }\end{array}$ & ECP & IL-5 & Eo & ECP/Eo & BM-Eo \\
\hline Control group & 20 & 4.93 & 1.88 & 103 & 0.040 & - \\
Patients & & $(3.67-6.32)$ & $(1.52-2.19)$ & $(80-140)$ & $(0.038-0.062)$ & \\
$\begin{array}{l}\text { Total } \\
\quad \text { Clonal }\end{array}$ & 69 & 19.5 & 2.16 & 755 & 0.028 & $10(8-12)$ \\
$\quad \begin{array}{l}\text { eosinophilia } \\
\text { Non-clonal }\end{array}$ & 28 & $(11.5-31.4)$ & $(1.74-2.72)$ & $(401-1500)$ & $(0.017-0.035)$ & \\
$\quad \begin{array}{l}\text { eosinophilia } \\
\text { with malignity }\end{array}$ & 25 & $(12.23-143.2)$ & $(1.93-2.68)$ & $(392-4469)$ & $(0.020-0.038)$ & $9(8-14.5)$ \\
$\quad \begin{array}{l}\text { Reactive } \\
\text { eosinophilia }\end{array}$ & 16 & 19.5 & 1.89 & 784 & 0.026 & $9(8-10.5)$ \\
\hline
\end{tabular}

Values are expressed as medians with inter-quartile range (IQR) in parenthesis.

differences in the median levels of IL-5 (Figure 2). Our results are not consistent with a previous study (9), in which IL-5 levels were much higher in clonal compared to non- clonal eosinophilia.

Regarding ECP/Eo ratio lower values (median, IQR) were obtained in patients comparative to control group $(0.028,0.017-0.035$ vs $0.040,0.038-0.062, \mathrm{p}<0.05)$ but there was no statistically significant difference among the 3 eosinophilic groups (Figure 3). As a limit for the analysis, we could not perform a proper dilution of samples with ECP values > $200 \mathrm{ng} / \mathrm{mL}$, because the diluent specifically recommended by the manufacturer was not available. The higher ECP values that had been obtained by diluting the samples would have influenced probably the levels of ECP/Eo ratio in clonal eosinophilia patients.

IL-5 and ECP/Eo levels did not help in distinguishing reactive eosinophilia with inflammation from other eosinophilic conditions.

Further, we divided patients having non-clonal eosinophilia with malignity in 2 groups: eosinophilic patients with non-clonal hematologic malignancy and eosinophilic patients with non hematologic malignancy (solid tumors). The first category comprised 20 patients with chronic lymphoproliferative diseases and the other category included 5 patients with solid tumors. A difference was registered only in IL-5 levels, patients with hematologic malignancy having higher values, but this finding may not be valid in all cases considering the small group of patients.

\section{Discussions}

Eosinophilia is frequently found in clinical practice and sometimes serves as a diagnostic indicator in certain hematologic malignancies. In both stem cell and myeloid malignancies, eosinophils arise from the neoplastic clone, while in most lymphoid malignancies, solid tumors and other reactive conditions eosinophilia is generated by eosinopoietic cytokines $(5,7)$. Few data have been published regarding the comparison between patients with clonal and reactive eosinophilia or between hematological and non-hematological disorders accompanied by eosinophilia.

We analyzed the eosinophilic activation degree within 3 eosinophilic conditions (clonal disorders, non-clonal eosinophilia with malignancy and reactive eosinophilia in inflammatory conditions).

\section{Clonal eosinophilia}

In AML, a high level of blood and bone marrow eosinophilia is infrequent, except AML- M4Eo (FAB) with chromosome 16 variants such as inv(16)(p13q22) or $\mathrm{t}(16 ; 16)$ 


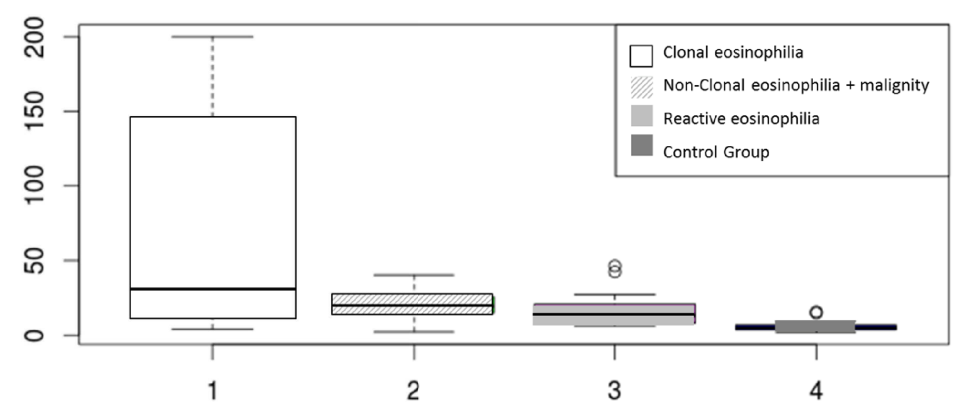

Figure 1. Serum ECP levels in different eosinophilia groups. The box plot indicates the median and IQR values of serum ECP levels.

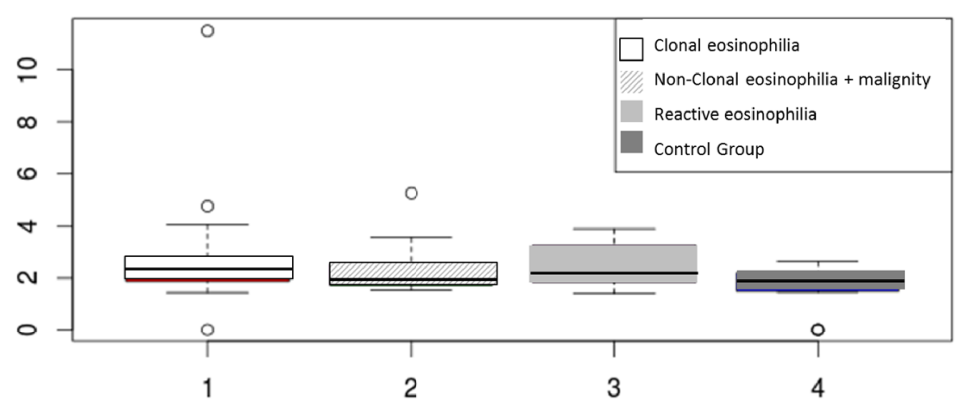

Figure 2. Serum IL-5 levels in different eosinophilia groups.

The box \& whisker plot indicates the median and IQR values of serum IL-5 levels.

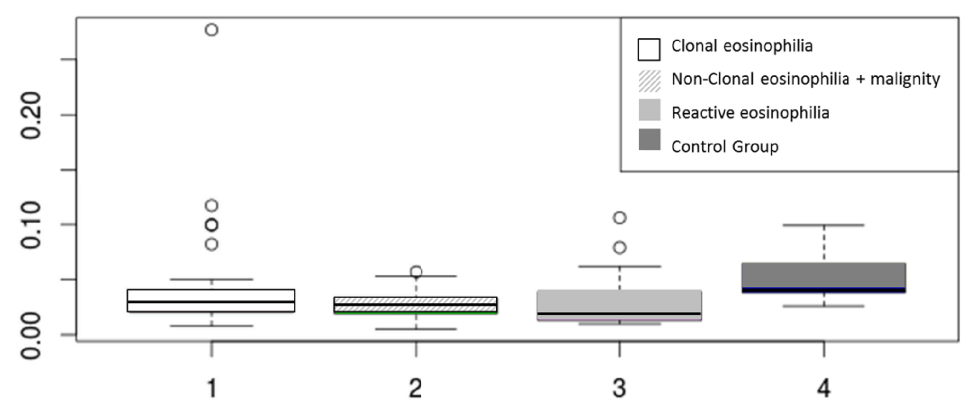

Figure 3. ECP/Eo values in different eosinophilia groups.

The box plot indicates the median and IQR values of ECP/Eo ratio.
AML-Eo cases eosinophils major atypia consists in positivity for naphthol-AS-chloroacetate esterase (NACE). This cytochemical feature is missing in eosinophils from normal or reactive conditions and most myeloid malignancies with eosinophilia (15). We investigated 6 patients with AML - 3 patients with AML-M4 (FAB) and inv(16)/ $\mathrm{t}(16 ; 16)$ and 3 patients with AMLM2 (FAB) and $t(8 ; 21)$. The highest ECP levels were observed in AMLM4 patients (>200 ng/mL). They also had high percentage of BM-Eo (> $20 \%$ ), mature and immature forms with morphological atypia and eosinophils containing a mixture of eosinophilic and basophilic granules. Eosinophilic granules showed positivity for (NACE).

In $\mathrm{Ph}+\mathrm{CML}$, eosinophils are a component of the malignant clone (14). Substantial eosinophilia is usually correlated with cytogenetic progression and occurs during accelerated or in blastic phase (14). We investigated 13 CML patients ( 7 of them were in chronic phase and 6 in accelerated phase). The highest values for ECP (> $200 \mathrm{ng} / \mathrm{mL}$ ) were observed in CML patients with significant eosinophilia $(>10 \%$ eosinophils in peripheral blood), important basophilia (>10\% basophils in peripheral blood) and trombocytosis (>1milion/mm3) or in accelerated phase. This observation (p13q22) with the chimeric fusion of $\mathrm{CBF} \beta$ and MYH1 genes (14). Also, eosinophilia may be present in a minority of cases of AML- M2 or M1 (FAB) with $\mathrm{t}(8 ; 21)(\mathrm{q} 22 \mathrm{q} 22)$ and AML1ETO fusion gene(11). AML- M4 (FAB) accompanied by inv(16) is characterized by an increase of mature and immature eosinophils in bone marrow (blood eosinophilia is lacking). In could sustain the existence of a common eosinophilbasophil precursor (16). Morphologic atypia seen in patients with CML were: hypersegmented nuclei, vacuolation, presence of immature forms, basophilic and eosinophilic granules in eosinophilic myelocytes and, occasionally, in mature eosinophils. The presence of mixed eosinophilic and basophilic granules in eosinophils may also indicate a common 
myeloid precursor for eosinophils and basophils. Leukocytes with hybrid granules could be interpreted as an argument for a neoplasia- related lineage infidelity (7).

In some IHES patients, it has been proved that eosinophils were clonal and, in other cases, patients with IHES progressed into a myeloid neoplasm (17). Moreover, before 2003 (when FIP1L1- PDGFR mutation was discovered), many patients were categorized as IHES (18). We investigated 4 patients with IHES. 3 of them responded to imatinib therapy, without evidence of any genetic anomalies. We considered that these 3 patients might carry a rearrangement or an overexpression of a gene which encodes for a tyrosine kinase. The fourth patient had a FIP1L1-PDGFR mutation and was also responsive to imatinib. Because of the suspected/demonstrated clonality of eosinophilia in these cases, we considered and included them in clonal eosinophilia group. Levels of serum ECP and IL-5 were not significant higher than other clonal eosinophilia cases and our explanation is based on the fact that these patients were already under treatment. Approximately $10 \%$ of all MDS cases are accompanied by eosinophilia. Eosinophilia at the time of diagnosis has prognostic implication, with an increasing possibility to transform into secondary AML and a decreased survival (19). It has been demonstrated that in some MDS cases, eosinophils belong to the malignant clone (20). The most common cytogenetic abnormalities in MDS with eosinophilia are located on chromosomes 5, 7 or 16 (20). We investigated 4 MDS patients - 2 with refractory cytopenia with multilineage dysplasia (RCMD) and 2 with refractory anemia with excess blasts (RAEB). One of the RMCD patients had $t(5 ; 12)(\mathrm{q} 33 ; \mathrm{p} 13)$ which could confirm the hypothesis that a genetic alteration involving chromosome 5 might generate the rearrangement of genes that regulate eosinophil differentiation (20). Both RAEB patients had monosomy 7. Previous studies showed that patients with MDS and monosomy
7 with more than $5 \%$ bone marrow eosinophils are patients with a great probability to develop secondary or therapy-related AML (20). We considered monosomy 7 in our patients as a poor prognosis element. Our MDS patients showed moderate ECP increases, but less than in CML or AML patients and normal IL-5 levels. All 4 MDS patients had mature and immature eosinophils in both peripheral blood and bone marrow, an incomplete segmentation of the nucleus in mature eosinophils (pseudo Pelger-Huet anomaly), disproportion of eosinophilic granules, ring shaped nucleus or vacuolated cytoplasm. Peripheral eosinophilia accompanies SM in up to $20 \%$ of cases and bone marrow biopsies often show eosinophilia (4). In our study we included only one patient with smoldering SM, mild peripheral and bone marrow eosinophilia, but no increase in ECP, IL-5 or ECP/Eo ratio. Among patients with clonal eosinophilia we observed the highest ECP levels in CML and AML- M4Eo patient. Regarding IL-5 and ECP /Eo ratio no significant differences were found.

\section{Non-clonal (reactive) eosinophilia in hematologic malignancies}

In this category we considered lymphoid neoplasms associated with eosinophilia (21): T$\mathrm{NLH}, \mathrm{HL}$ and less common B- NHL, NK-cell malignancies and other B-cell malignancies.

Clonal eosinophilia associated with $\mathrm{T}$ NHL is rare (6) and it is considered to be reactive in most of cases, being induced by excessive production of eosinophilopoietic cytokines (IL3, IL5 and GM-CSF) (which are generated by lymphoid cells). Lesional eosinophilia is most common with nodular sclerosis Hodgkin lymphoma and heavy eosinophilic tissue infiltration indicates a poor prognosis (22). Eosinophilia in Hodgkin lymphoma has been correlated with the expression of IL-5 mRNA by Reed-Sternberg cells and explained by the finding that cultured H-RS cells synthesize IL-5 and GM-CSF which are potent stimulators of eosinophils (23). In our group of eosinophilic 
patients there were 3 patients with T- NHL and 17 patients with B-cell limphoproliferative disorders while reviews indicate a higher incidence of eosinophilia in T- NHL (21). We included in our study group patients with MM, trying to explain the high percentage of eosinophils in bone marrow (>8\%). Recent experiments showed that plasma cells need an appropriate bone marrow microenvironment for survival and production of antibodies (24) Eosinophils make an important contribution to maintain this survival niche. In vitro studies demonstrated that eosinophils sustained the survival of plasma cells by releasing the proliferation-inducing ligand APRIL and IL -6 . Eosinophil roles in bone marrow may also include remodeling events such as bone regeneration by secreting IL- 4 and IL-6. These observations on mice await further studies in patients, because of potentially implications in diseases with abnormal expression of antibodies secreted by plasma B cells (e.g. autoimmune diseases or MM) (24). Among all eosinophilic patients with lymphoproliferative syndromes, the highest ECP and IL-5 levels were observed in patients with T-cell NHL. Within B-cell lymphoproliferative syndromes, CLL patients had the highest of ECP and IL-5 serum levels.

\section{solid tumors}

Non-clonal (reactive) eosinophilia in

Tumor-associated eosinophilia occurs in many solid tumors of epithelial origin (e.g. gastrointestinal, uterine, cervical, mammary, bladder, glioblastoma, pancreatic, lung, nasopharynx) (3). Eosinophilia may occur before diagnosing a neoplastic disease and may require an extended interval of observation (3). In solid tumors, eosinophils do not belong to the intrinsic malignant process and eosinophilia is induced by eosinophilopoietic and tumor cells-secreted cytokines (25). Previous studies showed that eosinophils are cytotoxic against tumor cells (3) and may be implicated in remodeling of the host connective tissue and blood vessels as a reaction to the growing tumor $(3,26)$. We investigated 5 patients with solid tumors ( 2 with colon cancer, 1 with lung cancer, 2 with uterine cancer). Regarding non-clonal hematological malignancies and solid tumors accompanied by eosinophilia, ECP levels and BM-Eo from both categories were comparable. IL-5 levels were higher in patients from the first category. These data may be not statistically significant due to the small number of patients.

\section{Reactive eosinophilia with inflammation}

Eosinophilia is mostly associated with allergy, drug reactions, infections, disorders of skin and connective tissue. In these cases eosinophilia is determined by stimulated Th2 cells that secrete high amounts of cytokines (GM-CSF, IL- 3, IL- 4, IL- 5 and IL-13) (2, 3, $5)$. These cytokines initiate autocrine loops that allow eosinophils to survive. It is improbable that assessment of cytokine levels solely would allow the distinction between clonal and nonclonal eosinophilia. Our patients with reactive eosinophilia and inflammation had a significantly higher median serum ECP value than that of the control group, but much lower than that of the clonal eosinophilia and non-clonal eosinophilia with malignity (Fig1) IL-5 and $\mathrm{ECP} /$ Eo levels did not help in distinguishing reactive eosinophilia with inflammation from other eosinophilic conditions. Non-clonal eosinophilia cases were not accompanied by cytochemical atypia and in these cases we rarely observed abnormal morphology of eosinophils (e.g. partial degranulation).

\section{Conclusions}

Eosinophilia is a diagnostic key in numerous hematologic and non-hematologic diseases. In patients with eosinophilia, it is important to certify or exclude clonality, to delineate an intrinsic malignant process or a reactive condition. Various biochemical and molecular/cytogenetic biomarkers are available, but we searched a noninvasive, relevant laboratory test that could distinguish variants of eosinophilic disorders. Our 
study shows that serum ECP levels could be helpful in early differentiation of clonal from nonclonal eosinophilia. IL-5 levels and ECP/ Eo were less useful, but their diagnostic value must be confirmed in larger studies. Serum ECP, IL-5 and ECP/Eo are not specific routine diagnostic tests and more sensitive biomarkers of eosinophil clonality need to be developed.

\section{Acknowledgements}

The authors thank the Imunology Department of Synevo Laboratories for kindly providing ECP and IL-5 kits.

This paper is partially supported by the Sectorial Operational Programme Human Resources Development, financed from the European Social Fund and by the Romanian Government under the contract number POSDRU/89/1,5/S/64153. Declaration of Interest: There is not any conflict of interests among the authors.

\section{Reference}

1. Rosenberg H.F.,Dyer K.D.,Foster P.S.

Eosinophils: changing perspectives in health and

Disease. Nat Rev Immunol. 2013 Jan;13(1):9-22.

2. Hogan SP, Rosenberg HF, Moqbel R, Phipps S, Foster PS, Lacy P, et al. Eosinophils: biological properties and role in health and disease. Clin Exp Allergy. 2008 May;38(5):709-50.

3. Jacobsen EA,Richard A. Helmers2, Lee JJ, Lee NA. The expanding role(s) of eosinophils in health and disease. Blood. 2012 Nov 8;120(19):3882-90.

4. Horny HP, Sotlar K, Valent P. Eosinophil, basophil, and mast cell infiltrates in the bone marrow: crossing the boundaries of diagnosis. Journal of Hematopathology. 2011;4(2):101-111.

5. Tefferi A, Patnaik MM, Pardanani A.

Eosinophilia: secondary, clonal and idiopathic. Br J Haematol. 2006 Jun;133(5):468-92.

6. Vardiman JW, Thiele J, Arber DA, Brunning RD, Borowitz MJ, Porwit A, et al. The 2008 revision of the WHO classification of myeloid neoplasms and acute leukemia: rationale and important changes. Blood. 2009 Jul 30;114(5):937-51.

7. Valent P. Pathogenesis, classification, and therapy of eosinophilia and eosinophilic disorders. Blood Rev. 2009 Jul;23(4):157-65.
8. Chusid MJ, Dale CD, West BC, Wolff SM .The hypereosinophilic syndrome: analysis of fourteen cases with review of the literature. Medicine (Baltimore). 1975 Jan;54(1):1-27.

9. Park YJ, Oh EJ, Park JW, Kim M, Han K. Plasma eosinophil cationic protein, interleukin-5, and ECP/Eo count ratio in patients with various eosinophilic diseases. Ann Clin Lab Sci. 2006;36(3):262-6.

10. Venge P, Bystrom J, Carlson M, Hakansson L, Karawacjzyk M, Peterson C, et al. Eosinophil cationic protein (ECP): molecular and biological properties and the use of ECP as a marker of eosinophil activation in disease. Clin Exp Allergy. 1999 Sep;29(9):1172-86.

11. Davies L, Gather U. The Identification of Multiple Outliers. Journal of the American Statistical Association. 1993 Sep;88(423):782-92.

12. Rousseeuw PJ, Croux C. Alternatives to the Median Absolute Deviation. Journal of the American Statistical Association. 1993 Sep;88(424):173-83.

13. Mizera I, Muller CH. Location-Scale Depth. Journal of the American Statistical Association. 2004 Dec;99(468):949-89.

14. Gotlib J. Eosinophilic myeloid disorders: new classification and novel therapeutic strategies. Curr Opin Hematol. 2010 Mar;17(2):117-24.

15. Liso V., Troccoli G., Specchia G. and Magno M. Cytochemical "normal" and "abnormal" eosinophils in acute leukemias. Am J Hematol. 1977;2(2): 123-31.

16. Karasuyama H, Mukai K, Tsujimura Y, Obata K. Newly discovered roles for basophils: a neglected minority gains new respect. Nat Rev Immunol. 2009 Jan;9(1): 9-13.

17. Chang HW, Leong KH, Koh DR, Lee SH. Clonality of isolated eosinophils in the hypereosinophilic syndrome. Blood. 1999 Mar 1;93(5):1651-7.

18. Cools J, DeAngelo DJ, Gotlib J, Stover EH, Legare RD, Cortes J, et al. A tyrosine kinase created by fusion of the PDGFRA and FIP1L1 genes as a therapeutic target of imatinib in idiopathic hypereosinophilic syndrome. N Engl J Med. 2003 Mar 27;348(13):1201-14.

19. Malcovati L, Germing U, Kuendgen A, Della Porta MG, Pascutto C, Invernizzi R, et al. Time-dependent prognostic scoring system for predicting survival and leukemic evolution in myelodysplastic syndromes. J Clin Oncol. 2007 Aug 10;25(23): 3503-10.

20. Matsushima T, Handa H, Yokohama A, Nagasaki J, 
Koiso H, Kin K, et al. Prevalence and clinical characteristics of myelodysplastic syndrome with bone marrow eosinophilia or basophilia. Blood. 2003 May 1;101(9):3386-90.

21. Roufosse F, Garaud S, de Leval L. Lymphoproliferative Disorders Associated With Hypereosinophilia. Semin Hematol. 2012 Apr;49(2):138-48.

22. von Wasielewski R, Seth S, Franklin J, Fischer R, Hubner K, Hansmann ML et al. Tissue eosinophilia correlates strongly with poor prognosis in nodular sclerosing Hodgkin's disease, allowing for known prognostic factors. Blood. 2000 Feb 15;95(4):1207-13.

23. Stanelle J, Doring C, Hansmann ML, Kuppers R. Mechanisms of aberrant GATA3 expression in classical Hodgkin lymphoma and its consequences for the cytokine profile of Hodgkin and Reed/Sternberg cells. Blood. 2010
Nov 18;116(20):4202-11.

24. Chu VT, Frohlich A, Steinhauser G, Scheel T, Roch T, Fillatreau S, et al. Eosinophils are required for the maintenance of plasma cells in the bone marrow. Nat Immunol. 2011 Feb; 12(2):151-9.

25. Simson L, Ellyard JI, Dent LA, Matthaei KI, Rothenberg ME, Foster PS, et al. Regulation of carcinogenesis by IL-5 and CCL11: a potential role for eosinophils in tumor immune surveillance. J Immunol. 2007 Apr 1;178(7):4222-9.

26. Cormier S, Taranova A, Bedient C, Nguyen T, Protheroe C, Pero R et al. Pivotal advance: Eosinophil infiltration of solid tumors is an early and persistent inflammatory host response. J Leukoc Biol. 2006 Jun; 79(6):1131-9. 